\title{
Selection of Test Systems for Estimation of Anti-aggregation Activity of Molecular Chaperones
}

\section{Boris I. Kurganov*}

Bach Institute of Biochemistry, Russian Academy of Sciences, Moscow, Russia

*Corresponding author: Boris IK, Bach Institute of Biochemistry, Russian Academy of Sciences, Moscow, Russia, Tel: +7(495)952-5641; Fax: +7(495)954-2732; Email: kurganov@inbi.ras.ru

Rec date: Apr 29, 2015; Acc date: Apr 30, 2015; Pub date: May 04, 2015

Copyright: () 2015 Boris IK. This is an open-access article distributed under the terms of the Creative Commons Attribution License, which permits unrestricted use, distribution, and reproduction in any medium, provided the original author and source are credited.

\section{Editorial}

Searching the agents that are capable of effectively suppressing protein aggregation and elaboration of the corresponding test systems are among the most important problems of modern biochemistry and analytical biochemistry [1-7]. To characterize the anti-aggregation activity of different agents including chaperones of protein nature and low-molecular-weight chemical chaperones, test systems where the initial state of a target protein is the native protein that undergoes unfolding and subsequent aggregation under the action of different factors are mostly used. Unfolding of the target protein can be caused by heating at elevated temperatures. For several proteins the unfolding process can be initiated by the cleavage of S-S bonds in the protein molecule. Dithiothreitol (DTT)-induced aggregation was demonstrated, for example, for a-lactalbumin, insulin, lysozyme and bovine serum albumin (BSA).

When interpreting the effect of chaperone on the rate of aggregation of the target protein, we should realize in what kinetic regime proceeds the aggregation process. By convention test systems can be classified into two types. One of the types corresponds to the kinetic regime where the rate-limiting stage of the general process of aggregation is the stage of protein unfolding (type A in Table 1). The other type corresponds to the kinetic regime where the rate-limiting stage of the general process of aggregation is the stage of aggregation of the unfolded protein (type B in Table 1).

\begin{tabular}{|c|c|c|}
\hline $\begin{array}{l}\text { Type of test system in accordance with } \\
\text { the kinetic regime of aggregation }\end{array}$ & $\begin{array}{l}\text { The order of } \\
\text { aggregation with } \\
\text { respect to the } \\
\text { protein }(n)\end{array}$ & Examples \\
\hline $\begin{array}{l}\text { Type A } \\
N \stackrel{\text { sovv stage }}{\longrightarrow} U \stackrel{\text { tass stage }}{\longrightarrow} \text { Aggregates }\end{array}$ & $n=1$ & $\begin{array}{l}\text { DTT-induced aggregation of } \\
\text { BSA [16]. }\end{array}$ \\
\hline $\begin{array}{l}\text { Type B } \\
N \stackrel{\text { fast tage }}{\longrightarrow} U \stackrel{\text { slow stage }}{\longrightarrow} \text { Aggregates }\end{array}$ & $n \geq 2$ & $\begin{array}{l}\text { Thermal aggregation of BSA } \\
\text { at } 90^{\circ} \mathrm{C}[21] \text {; DTT-induced } \\
\text { aggregation of } \alpha \text {-lactalbumin } \\
{[10,17-19] \text {. }}\end{array}$ \\
\hline $\begin{array}{l}\text { Type C } \\
U \longrightarrow \text { Aggregates }\end{array}$ & $n \geq 2$ & $\begin{array}{l}\text { Thermal aggregation of UV- } \\
\text { irradiated } \mathrm{Ph} b[30,31] \text { and } \\
\text { GAPDH [32]. }\end{array}$ \\
\hline
\end{tabular}

Table 1: Classification of test systems designed to estimate the antiaggregation activity of molecular chaperones.

To characterize the kinetic regime of aggregation of the target protein, we should determine the order of aggregation with respect to protein $(\mathrm{n})$. The $\mathrm{n}$ value is calculated from the dependence of the initial rate of aggregation $\left(\mathrm{v}_{\mathrm{agg}}\right)$ on the initial concentration of the protein $(\mathrm{P})$ :

$$
\text { Vagg }=\left(\frac{\mathrm{d}[\mathrm{P}] \mathrm{agg}}{\mathrm{d} t}\right)_{0}=\text { const }[\mathrm{P}]^{n} \cdot(1)
$$

In this expression $[\mathrm{P}]_{\mathrm{agg}}$ is the concentration of the aggregated protein and $[\mathrm{P}]$ is the initial concentration of the protein.

To follow the kinetics of protein aggregation, the methods based on the registration of the light scattering intensity are widely used because of the possibility of the continuous monitoring the aggregation process. To apply the kinetic data obtained by this means for elucidation of the aggregation mechanism and quantitative estimation of the effects of different agents on the aggregation rate, the relationship between increment in the light scattering intensity and the amount of the aggregated protein should be determined using the methods that allow the concentration of the aggregated protein to be directly registered. To characterize the initial rate of aggregation, the initial parts of kinetic curves registered by measurement of increment in the light scattering intensity were approximated by the quadratic function [8-15]:

$$
I=I_{0}+\left[K_{\mathrm{LS}}\left(t-t_{0}\right)\right]^{2}(2)
$$

In this empiric equation $\mathrm{K}_{\mathrm{LS}}$ is a constant that can be considered as a measure of the initial rate of aggregation and $t_{0}$ is the duration of the lag phase. To substantiate the propriety of using parameter $\mathrm{K}_{\mathrm{LS}}$ for characterization of the initial rate of aggregation, the comparison of the kinetic data obtained by measuring the light scattering intensity with direct determination of the amount of the aggregated protein should be carried out. Such a comparison was made, for example, for DTT-induced aggregation of BSA $\left(45^{\circ} \mathrm{C} ; 100 \mathrm{mM}\right.$ Na-phosphate buffer, $\mathrm{pH}$ 7.0; $2 \mathrm{mM}$ DTT) [16]. Asymmetric flow field flow fractionation was used for estimating the concentration of the aggregated protein. It has been shown that the initial rate of aggregation $\left(\mathrm{v}_{\mathrm{agg}}\right)$ and parameter $\mathrm{K}_{\mathrm{LS}}$ are linear functions of the initial concentration of the target protein (BSA). By this is meant that parameter $\mathrm{K}_{\mathrm{LS}}$ can be used for characterization of the initial rate of aggregation. Thus, test system based on DTT-induced aggregation of BSA belongs to test systems where the rate-limiting stage of the general process of aggregation is the stage of protein unfolding $(n=1$; test system of type A).

On the basis of analysis of the dependence of parameter $\mathrm{K}_{\mathrm{LS}}$ on the protein concentration the conclusion has been made that DTTinduced aggregation of $\alpha$-lactalbumin proceeds in the kinetic regime where the rate-limiting stage is the stage of aggregation of unfolded protein molecules. The value of $\mathrm{n}$ for the aggregation process was found to be $2.5 \pm 0.2$ ( $80 \mathrm{mM}$ Hepes buffer, $\mathrm{pH} 6.8$, containing $0.1 \mathrm{M}$ $\mathrm{NaCl} ; 37^{\circ} \mathrm{C}$ ) [17]. The data obtained in our earlier works are consistent with this conclusion $[10,18,19]$. In Table 1 this test system is classified as a test system of type B. 
It should be noted that in the case thermal aggregation of target proteins elevation of temperature can result in the change in the kinetic regime of the aggregation process with realization of the kinetic regime of type $B$ at high temperatures $[20,21]$.

Consider the action of the agents which are capable of forming the reversibly dissociating complexes with the target protein. If we use test systems of type B, the observed effects of the agents under study directly characterize the action of the agent on the aggregation stage. For example, Shah et al. studied the effect of arginine on heat-induced aggregation of $\mathrm{BSA}$ at $90^{\circ} \mathrm{C}$ [21]. It was demonstrated that relatively low concentrations of arginine enhanced thermal aggregation of BSA, whereas the high concentrations of arginine suppressed the aggregation process. The dual effect of arginine was reported also by Smirnova et al. [22] who studied DTT-induced aggregation of $\alpha$ lactalbumin.

When employing test systems of type A, we should realize that the agents exerting some action on the stability of the native form of the target protein will eventually affect the initial rate of aggregation. The agents stabilizing protein structure will retard protein aggregation. On the contrary, the agents causing protein destabilization will accelerate protein aggregation. To interpret the effects of different agents on aggregation of target proteins, the additional experiments on protein stability in the presence of the agents under study should be carried out. It is worth noting that test systems of type A can be used for screening of ligands specifically interacting with proteins on the basis of measurements of the aggregation rate in the presence of ligands under study [23-26].

As for chaperones of the protein nature forming tight complexes with the target protein, they will reveal the anti-aggregation activity in all test systems regardless of what stage of the general process of aggregation (protein unfolding or sticking of unfolded protein forms) is rate-determining. For example, in the work by Borzova et al. [27] the suppression of DTT-induced aggregation of BSA (a test system of type A) by $\alpha$-crystallin, a representative of the family of small heat shock proteins, was studied. The principles of the quantitative estimation of the anti-aggregation activity of protein chaperones have been formulated in our works $[13,14,27]$. It is interesting that $\alpha$-crystallin can exert the anti-aggregation activity, even though this chaperone induces destabilization of the target protein. Such a situation is realized, for example, in experiments on thermal aggregation of glyceraldehyde-3-phosphate dehydrogenase (GAPDH) in the presence of $\alpha$-crystallin [28]. Destabilization of the tetrameric GAPDH molecule is due to the interaction of $\alpha$-crystallin with the dissociated forms, which are formed in the course of thermal denaturation of GAPDH [29].

To overcome the difficulties connected with the interpretation of the mechanisms of protein aggregation suppression by molecular chaperones, we proposed to use test systems based on thermal aggregation of target proteins denatured by ultraviolet radiation. Glycogen phosphorylase $b(\mathrm{Ph} b)$ and GAPDH from rabbit skeletal muscle were used as target proteins [30-32]. The advantage of these test systems (type $\mathrm{C}$ in Table 1) is the possibility to estimate the direct effect of the chaperones on aggregation of the target protein. Interestingly to compare the effect of chemical chaperone, 2hydroxypropyl- $\beta$-cyclodextrin (HP- $\beta$-CD), on thermal aggregation of intact and UV-irradiated GAPDH. It has been shown that HP- $\beta$-CD accelerates thermal aggregation of intact GAPDH. Such an effect of HP- $\beta-C D$ is due to destabilization of the protein molecule $[9,12]$. However, when the test system based on aggregation of UV-irradiated
GAPDH was used, the suppressing effect of HP- $\beta$-CD was observed [32]. This protective action of HP- $\beta-C D$ is typical for cyclodextrins [6]. It is evident that there is a dual effect of HP- $\beta-C D$ in the case of aggregation of intact GAPDH. On the one hand, HP- $\beta$-CD favors GAPDH denaturation and, consequently, aggregation of denatured protein. On the other hand, this agent suppresses protein aggregation. The first effect is prevailing, resulting in acceleration of GAPDH aggregation.

The efficiency of chemical chaperone in suppression of protein aggregation in test system of type $\mathrm{A}$ is determined by its affinity to the native form of the target protein, whereas in the case of test systems of type $\mathrm{C}$ the determining factor is the affinity of chemical chaperone to the unfolded form of the target protein. To characterize the affinity of chemical chaperone to the protein, the dependences of the relative initial rate of aggregation $\mathrm{K}_{\mathrm{LS}} / \mathrm{K}_{\mathrm{LS}, 0}$ on the concentration of chemical chaperone can be used. Consider, for example, the suppression of DTT-induced aggregation of BSA by arginine (test system of type A, Figure 1) and suppression of thermal aggregation of UV-irradiated GAPDH by HP- $\beta$-CD (test system of type C, Figure 2 ). The dependences of $\mathrm{K}_{\mathrm{LS}} / \mathrm{K}_{\mathrm{LS}, 0}$ on the concentration of chemical chaperone (L) were analyzed using Hill equation [33].

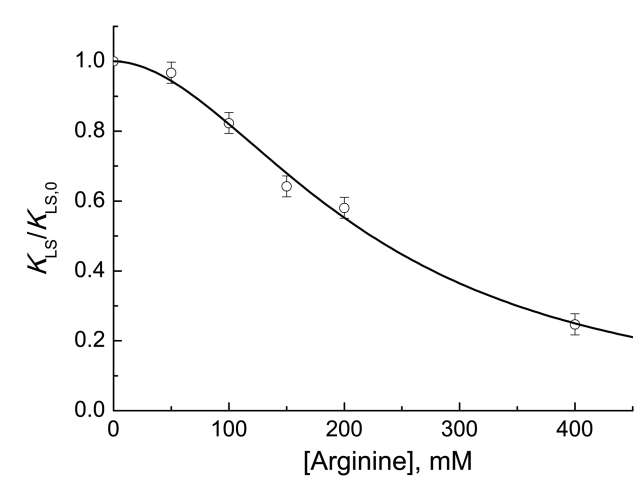

Figure 1: Test system of type A. Effect of arginine on DTT-induced aggregation of BSA. The dependence of the relative initial rate of aggregation $\left(\mathrm{K}_{\mathrm{LS}} / \mathrm{K}_{\mathrm{LS}, 0}\right)$ of $\mathrm{BSA} \quad(1.0 \mathrm{mg} / \mathrm{ml})$ on arginine concentration $\left(45^{\circ} \mathrm{C} ; 100 \mathrm{mM}\right.$ Na-phosphate buffer, pH 7.0; $2 \mathrm{mM}$ DTT) is plotted for the data presented in [27]. Circles are experimental data. The solid curve is drawn using Eq. (3) at $[\mathrm{L}]_{0.5}=223 \mathrm{mM}$ and $h=1.9$.

$$
\frac{K \mathrm{LS}}{K \mathrm{LS}, 0}=\frac{1}{1+([\mathrm{L}] /[\mathrm{L}] 0.5)^{h}},(3)
$$

Where $[\mathrm{L}]_{0.5}$ is the semi-saturation concentration, i.e., the

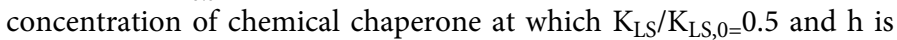
the Hill coefficient. Parameter $[\mathrm{L}]_{0.5}$ can be considered as a measure of the affinity of chemical chaperone to the protein. The lower the $[\mathrm{L}]_{0.5}$ value, the higher is the affinity of chemical chaperone to the protein. The following values of parameters were found for suppression of DTT-induced aggregation of BSA by arginine: $[\mathrm{L}]_{0.5}=223 \pm 8 \mathrm{mM}$ and $h=1.9 \pm 0.1$ (coefficient of determination $\mathrm{R}^{2}$ is equal to 0.9913 ). In the case of thermal aggregation of UV-irradiated GAPDH in the presence of HP- $\beta$-CD the estimated values of parameters were $[\mathrm{L}]_{0.5}=23 \pm 2$ $\mathrm{mM}$ and $h=1.17 \pm 0.14 \quad\left(\mathrm{R}^{2}=0.9815\right)$. The first value of $[\mathrm{L}]_{0.5}$ characterizes the affinity of chemical chaperone to the native protein, 
whereas the second value of $[\mathrm{L}]_{0.5}$ is a measure of the affinity of chemical chaperone to the denatured protein.

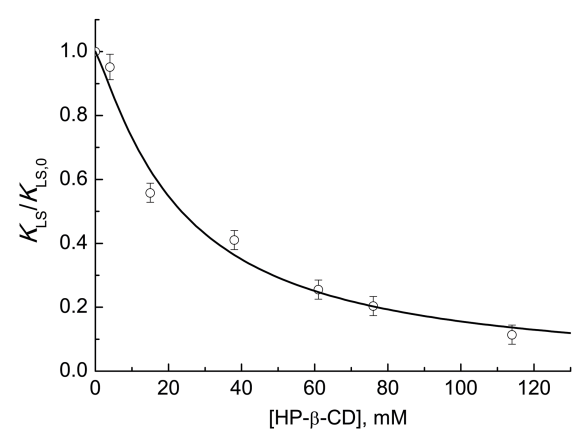

Figure 2: Test system of type C. Effect of HP- $\beta-C D$ on aggregation of UV-irradiated GAPDH. The dependence of the relative initial rate of aggregation $\left(\mathrm{K}_{\mathrm{LS}} / \mathrm{K}_{\mathrm{LS}, 0}\right)$ of UV-irradiated GAPDH $(0.4$ $\mathrm{mg} / \mathrm{ml})$ on HP- $\beta$-CD concentration $\left(37^{\circ} \mathrm{C} ; 50 \mathrm{mM}\right.$ Na-phosphate buffer, $\mathrm{pH}$ 7.5) is plotted for the data presented in [32]. Circles are experimental data. The solid curve is drawn using Eq. (3) at $[\mathrm{L}]_{0.5}=23 \mathrm{mM}$ and $h=1.17$.

In summary, when analyzing the anti-aggregation activity of molecular chaperones, one should take into account the kinetic regime of the aggregation process used in definite test system. This is true in regard to test systems based on protein unfolding followed by aggregation of unfolded protein molecules as well as to test systems based on aggregation accompanying refolding of target protein from urea (or guanidine hydrochloride)-denatured state.

\section{Acknowledgement}

This study was funded by the Russian Foundation for Basic Research (grant 14-04-01530-a) and the Program "Molecular and Cell Biology" of the Presidium of the Russian Academy of Sciences.

\section{References}

1. Carpenter JF, Kendrick BS, Chang BS, Manning MC, Randolph TW (1999) Inhibition of stress-induced aggregation of protein therapeutics. Methods Enzymol 309: 236-255.

2. Banga AK (2006) Therapeutic Peptides and Proteins. Formulation, Processing, and Delivery Systems. CRC Press, Taylor \& Francis Group, Boca Raton, FL.

3. Hamada H, Arakawa T, Shiraki K (2009) Effect of additives on protein aggregation. Curr Pharm Biotechnol 10: 400-407.

4. Wang W, Li N, Speaker S (2010) External factors affecting protein aggregation. In: Wang W, Roberts CJ (Eds) Aggregation of Therapeutic Proteins. John Wiley \& Sons, Inc., Hoboken, New Jersey 119-204.

5. Shukla D, Schneider CP, Trout BL (2011) Molecular level insight into intra-solvent interaction effects on protein stability and aggregation. Adv Drug Deliv Rev 63: 1074-1085.

6. Serno T, Geidobler R, Winter G (2011) Protein stabilization by cyclodextrins in the liquid and dried state. Adv Drug Deliv Rev 63: 1086-1106.

7. Kurganov BI (2012) Fundamental aspects of conformational lability of proteins. Biochem Anal Biochem 1: e107.

8. Kurganov BI (1998) Kinetics of heat aggregation of proteins. Biochemistry (Mosc) 63: 364-366
9. Maloletkina OI, Markosyan KA, Asriyants RA, Orlov VN, Kurganov BI (2009) Antichaperone activity of cyclodextrin derivatives. Dokl Biochem Biophys 427: 199-201.

10. Bumagina ZM, Gurvits BY, Artemova NV, Muranov KO, Yudin IK, et al. (2010) Mechanism of suppression of dithiothreitol-induced aggregation of bovine alpha-lactalbumin by alpha-crystallin. Biophys Chem 146: 108-117.

11. Maloletkina OI, Markossian KA, Belousova LV, Kleimenov SY, Orlov VN, et al. (2010) Thermal stability and aggregation of creatine kinase from rabbit skeletal muscle. Effect of 2-hydroxypropyl-beta-cyclodextrin. Biophys Chem 148: 121-130.

12. Maloletkina OI, Markossian KA, Asryants RA, Semenyuk PI, Makeeva VF, et al. (2010) Effect of 2-hydroxypropyl-beta-cyclodextrin on thermal inactivation, denaturation and aggregation of glyceraldehyde-3-phosphate dehydrogenase from rabbit skeletal muscle. Int J Biol Macromol 46: 487-492.

13. Kurganov BI (2013) How to quantify the chaperone-like (anti-aggregation) activity? Biochem Anal Biochem 2: el36.

14. Kurganov BI (2013) Antiaggregation activity of chaperones and its quantification. Biochemistry (Mosc) 78: 1554-1566.

15. Kurganov BI (2014) Estimation of chaperone-like activity using test systems based on protein amyloid aggregation. Biochem Anal Biochem 3: e160.

16. Borzova VA, Markossian KA, Kara DA, Kurganov BI (2015) Kinetics of dithiothreitol-induced aggregation of bovine serum albumin. Int J Biol Macromol, in press.

17. Chebotareva NA, Filippov DO, Kurganov BI (2015) Effect of crowding on several stages of protein aggregation in test systems in the presence of ?crystallin. Int J Biol Macromol, in press.

18. Borzova VA, Markossian KA, Kurganov BI (2014) Relationship between the initial rate of protein aggregation and the lag period for amorphous aggregation. Int J Biol Macromol 68: 144-150.

19. Borzova VA, Markossian KA, Muranov KO, Polyansky NB, Kleymenov SY, et al. (2015) Quantification of anti-aggregation activity of UVirradiated a-crystallin. Int J Biol Macromol 73: 84-91.

20. Fedurkina NV, Belousova LV, Mitskevich LG, Zhou HM, Chang Z, et al. (2006) Change in kinetic regime of protein aggregation with temperature increase. Thermal aggregation of rabbit muscle creatine kinase. Biochemistry (Mosc) 71: 325-331.

21. Shah D, Shaikh AR, Peng X, Rajagopalan R (2011) Effects of arginine on heat-induced aggregation of concentrated protein solutions. Biotechnol Prog 27: 513-520.

22. Smirnova E, Safenkova I, Stein-Margolina B, Shubin V, Gurvits B (2013) Larginine induces protein aggregation and transformation of supramolecular structures of the aggregates. Amino Acids 45: 845-855.

23. Senisterra GA, Markin E, Yamazaki K, Hui R, Vedadi M, et al. (2006) Screening for ligands using a generic and high-throughput light-scatteringbased assay. J Biomol Screen 11: 940-948.

24. Senisterra GA, Ghanei H, Khutoreskaya G, Dobrovetsky E, Edwards AM (2010) Assessing the stability of membrane proteins to detect ligand binding using differential static light scattering. J Biomol Screen 15: 314-320.

25. Eronina T, Borzova V, Maloletkina O, Kleymenov S, Asryants R, et al. (2011) A protein aggregation based test for screening of the agents affecting thermostability of proteins. PLoS One 6: e22154.

26. Kurganov BI (2013) Thermal denaturation and aggregation assays in analytical biochemistry. Biochem Anal Biochem 2: e143.

27. Borzova VA, Markossian KA, Kara DA, Chebotareva NA, Makeeva VF, et al. (2013) Quantification of anti-aggregation activity of chaperones: a testsystem based on dithiothreitol-induced aggregation of bovine serum albumin. PLoS One 8: e74367.

28. Khanova HA, Markossian KA, Kleimenov SY, Levitsky DI, Chebotareva NA, et al. (2007) Effect of alpha-crystallin on thermal denaturation and aggregation of rabbit muscle glyceraldehyde-3-phosphate dehydrogenase. Biophys Chem 125: 521-531. 
Citation: Boris I. Kurganov (2015) Selection of Test Systems for Estimation of Anti-aggregation Activity of Molecular Chaperones. Biochem Anal Biochem 4: e155. doi:10.4172/2161-1009.1000e155

Page 4 of 4

29. Chebotareva NA, Kurganov BI, Muranov KO, Asryants RA, Ostrovsky MA (2009) Role of thermoinduced dissociation in interaction between alphacrystallin as an oligomeric chaperone and glyceraldehyde-3-phosphate dehydrogenase as an oligomeric protein substrate. Dokl Biochem Biophys 428: 245-248.

30. Roman SG, Chebotareva NA, Eronina TB, Kleymenov SY, Makeeva VF, et al. (2011) Does the crowded cell-like environment reduce the chaperonelike activity of $\alpha$-crystallin? Biochemistry 50: 10607-10623.

31. Roman SG, Chebotareva NA, Kurganov BI (2012) Concentration dependence of chaperone-like activities of $\hat{I} \pm$-crystallin, $\hat{\mathrm{I}} \pm \mathrm{B}$-crystallin and proline. Int J Biol Macromol 50: 1341-1345.
32. Maloletkina OI, Markossian KA, Chebotareva NA, Asryants RA, Kleymenov SY, et al. (2012) Kinetics of aggregation of UV-irradiated glyceraldehyde-3-phosphate dehydrogenase from rabbit skeletal muscle. Effect of agents possessing chaperone-like activity. Biophys Chem 163-164: 11-20.

33. Kurganov BI (1982) Allosteric Enzymes. Kinetic Behaviour. John Wiley \& Sons, Chichester. 